\title{
Transverse Rupture Strength of a PM Tool Steel
}

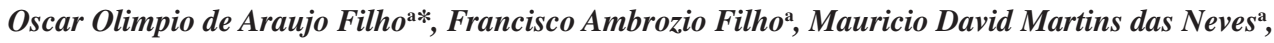 \\ Odília Cordeiro de Souza Ribeiro ${ }^{\text {a }}$, Cesar Henrique Lopes da Silva ${ }^{\text {b }}$
}

\author{
a IPEN, Instituto de Pesquisas Energéticas e Nucleares, \\ Av. prof. Lineu Prestes, 2242, Cidade Universitária, 05508-000 São Paulo, Brazil \\ ${ }^{\mathrm{b}}$ Hurth Infer Indústria de Máquinas e Ferramentas Ltda, \\ Av. Rudolfo Dafferner, 280, 180086-380 Sorocaba - SP, Brazil
}

Received: November 23, 2003; Revised: February 16, 2005

\begin{abstract}
Powder Metallurgy has been reported as a suitable alternate processing route for the manufacture of tool steels. The advantage of this technique is in being able to obtain a refined and more uniform microstructure that improves properties such high wear resistance and toughness. A molybdenum containing AISI M3:2 tool steel, (trade name Sinter 23), manufactured from spherical gas-atomized powders by hot isostatic pressing followed by hot working was tested in three-point bending tests after various heat treatments. Transverse rupture strength (TRS) samples were cut and heat treated at four distinct austenitizing temperatures. Each austenitizing temperature was combined with three tempering temperatures, giving a total of twelve different hardening conditions. Hardness tests were carried out to establish correlations among the effectiveness of heat treatment, the hardness values and the TRS results. At least five parallel samples were tested in each heat treatment condition.
\end{abstract}

Keywords: powder metallurgy, high speed steels, heat treatment, transverse rupture strength

\section{Introduction}

Since the introduction of the first prototype by Taylor and White in the beginning of the 1900's, high speed steels (HSS) have been used for a long time to manufacture cutting tools. They have been used widely because of their versatile properties and in many applications compete with cemented carbides ${ }^{1,2}$. The microstructure of this tool steel after a hardening treatment (austenitizing and quenching followed by tempering) consists of a matrix of martensite embedded with carbides rich in tungsten, molybdenum and vanadium, and this leads to useful properties such as wear resistance and toughness. This specific combination of properties, together with its low cost makes this tool steel the preferred material in many applications such as cutting procedures. The conventional route for the manufacture of HSS (ingot casting followed by hot working) produces a material with carbide cell structures that promotes anisotropic properties. On the other hand, the powder metallurgy (PM) method has been successfully used as an alternate process to obtain products with better distribution of smaller carbides in a manner that anisotropy of properties is not observed, or at least minimized to a large extent. In this investigation, a commercial molybdenum containing high speed steel named Sinter 23 that was obtained by a PM technique of hot isostatic pressing followed by hot working, was heat treated to give a total of twelve different hardening conditions, and then submitted to three-point bending tests to determine the transverse rupture strength as a function of the heat treatment procedure ${ }^{3-5}$.

\section{Literature Review}

The ability to retain high hardness even when metals were cut at high speeds resulted in this particular group of tool steels to be known as high speed steels (HSS). The first high speed steel named T1 was developed by the Crucible Steel Company. The procedure used by this company consisted of increasing the quantity of alloying elements, such as tungsten, to increase the hardness during air cooling from a high temperature, while most other steels required water quenching for hardening. T1 or 18-4-1 high speed steel has the following composition: $18 \%$ of tungsten, $4 \%$ chromium and $1 \%$ vanadium, and remained popular until it was replaced by a new product containing molybdenum as a strong carbide former, instead of some of the tungsten originally present in the T1 steel. The possibility of replacing tungsten with molybdenum reduces the cost of the steel, as molybdenum, with a lower atomic weight and about one half that of tungsten, has the advantage that only about one half the amount of molybdenum, compared to tungsten, produces the same effect, as a carbide former ${ }^{6}$. A consequence of replacing tungsten with moybdenum led to two classes of high speed steels: group $\mathrm{M}$ or molybdenum high speed steels and group $\mathrm{T}$ or tungsten high speed steels. The two groups are equivalent in general, including their performance and ability to harden.

Powder Metallurgy (PM) overcomes problems that are inherent in the conventional processing route (ingot casting followed by hot working), such as coarse carbides structures due to the long freezing range and consequent segregation. Hot working breaks these carbide cells to a certain extent and produces carbide stringers aligned in the deformation direction. PM techniques address some issues related to high speed steel technology, especially those related to obtaining products with improved distribution of fine carbides. These result from the increased cooling rates during solidification and highly alloyed compositions, and which cannot be attained by conventional technique $\mathrm{e}^{7-11}$.

\section{Experimental}

The AISI M3:2 Sinter 23 manufactured from atomized powder by HIP plus hot working was supplied as the starting material in the form of an annealed hot rolled round bar $57 \mathrm{~mm}$ in diameter. The microstructure of the as-received Sinter 23 consisted of a matrix of ferrite embedded with carbides rich in tungsten, molybdenum and vanadium (HB 278). The chemical composition of PM Sinter 23 is presented in Table 1.

Transverse rupture strength samples were cut according to

*e-mail: oscaroaf@ipen.br 
ASTM B 528-99 standard and given hardening treatments which consisted of austenitizing for 3 minutes at four different temperatures (1140, 1160, 1180 and $1200{ }^{\circ} \mathrm{C}$ ) followed by air quenching. The tempering treatments consisted of a triple temper, 2 hours at 540, 560 (secondary hardening peak) and $580^{\circ} \mathrm{C}$. Triple tempering treatment is necessary for Sinter 23 because of the increase in retained austenite, due to higher carbide dissolution, observed in the HIPed high speed steel. The heat treatments were carried out in a salt bath. After heat treatment, the samples were ground to their final dimensions of $6.35 \times 12.7 \times 31.7 \mathrm{~mm}$, fractured in a three-point bending test with a span of $25.4 \mathrm{~mm}$ to determine the transverse rupture strength (TRS). The transverse rupture strength was determined only in the transverse direction, as the material revealed an isotropic microstructure, and therefore isotropy in properties. At least five samples were fractured for each hardening condition. Vickers hardness tests were carried out to evaluate the effects of heat treatment and transverse rupture strength as a function of hardening treatment.

\section{Results and Discussion}

The as-received Sinter 23 was examined in a scanning electron microscope and its hardness determined to evaluate its machinability. Characterization of the structure and microstructure of annealed Sinter 23 was the object of a previous work. The scanning electron microscopy results of material submitted to hardening treatments showed no significant difference in the sizes and distribution of carbides. Scanning electron micrographs of Sinter 23, austenitized at $1140,1160,1180$ and $1200^{\circ} \mathrm{C}$ and tempered at the secondary hardening peak at $560{ }^{\circ} \mathrm{C}$ are shown in Figures 1-4. The types of carbides shown in Figure 5 were identified by microanalysis using EDS and the semi-quantitative results are shown in Figures 6 and 7. The carbides were of the type $\mathrm{M}_{6} \mathrm{C}$ and $\mathrm{MC}$. The $\mathrm{M}_{6} \mathrm{C}$ type carbide is predominantly rich in molybdenum and tungsten but could also contain chromium and vanadium. The MC type carbide corresponds almost entirely to vanadium carbide, which is extremely hard, abrasion resistant and

Table 1. Chemical composition of PM Sinter 23. Weight percent and iron balance.

\begin{tabular}{ccccccccccc}
\hline Sinter 23 & $\mathrm{C}$ & $\mathrm{Si}$ & $\mathrm{Mn}$ & $\mathrm{Cr}$ & $\mathrm{Mo}$ & $\mathrm{W}$ & $\mathrm{V}$ & $\mathrm{S}$ & $\mathrm{P}$ \\
\hline Wt. $(\%)$ & 1.31 & 0.64 & 0.36 & 4.04 & 4.98 & 6.16 & 3.02 & 0.01 & 0.021 \\
\hline
\end{tabular}

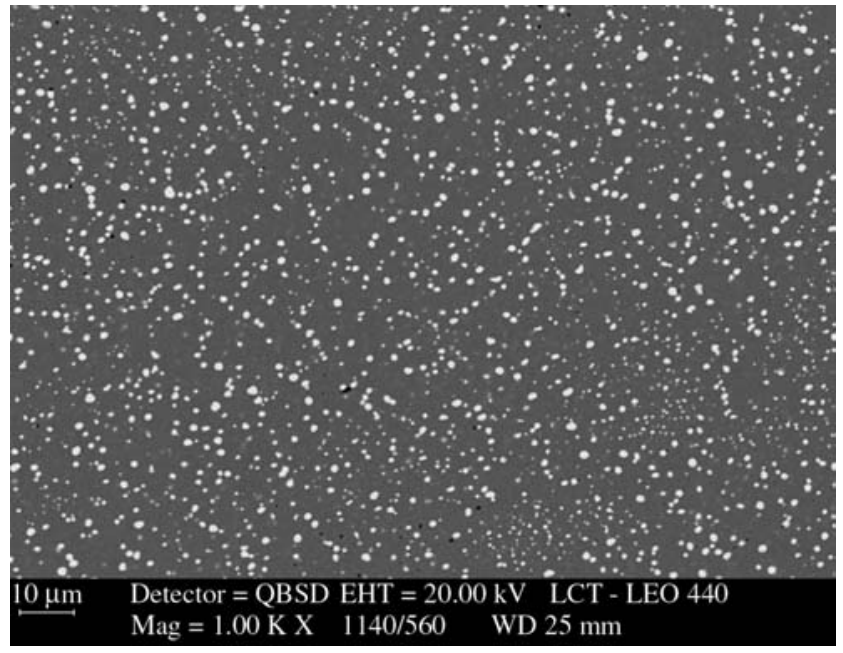

Figure 1. Scanning electron micrograph of Sinter 23 austenitized at $1140{ }^{\circ} \mathrm{C}$ and tempered at $560{ }^{\circ} \mathrm{C}$.

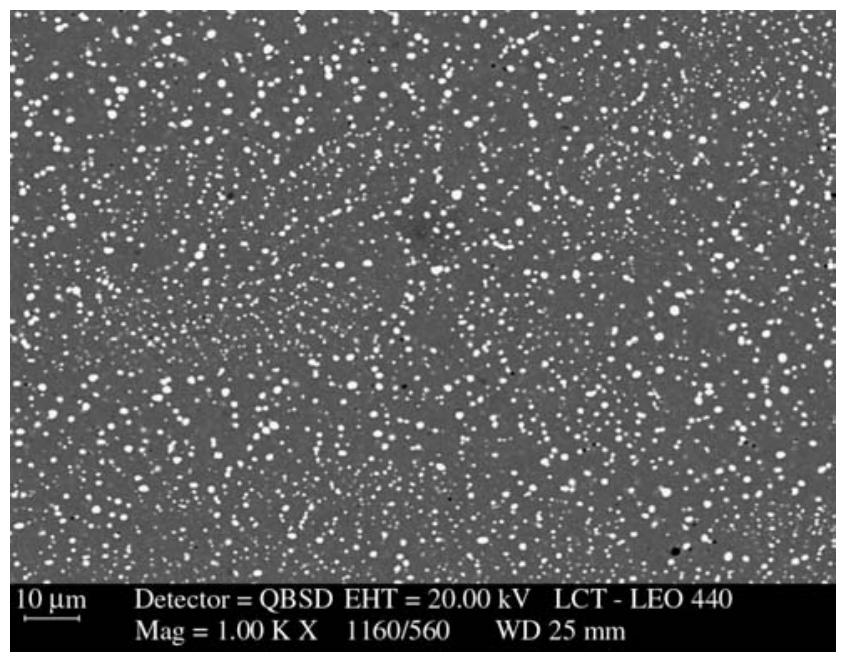

Figure 2. Scanning electron micrograph of Sinter 23 austenitized at $1160{ }^{\circ} \mathrm{C}$ and tempered at $560{ }^{\circ} \mathrm{C}$.

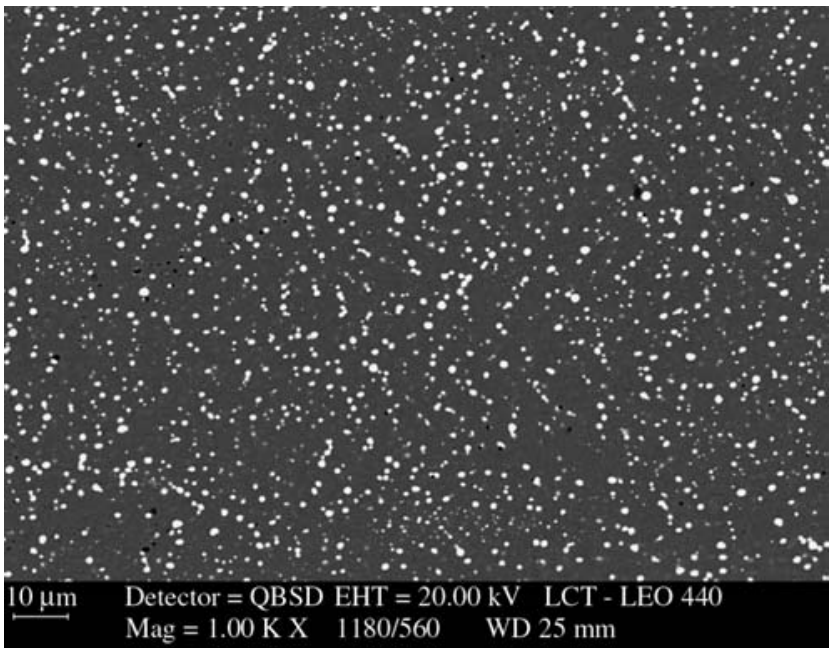

Figure 3. Scanning electron micrograph of Sinter 23 austenitized at $1180{ }^{\circ} \mathrm{C}$ and tempered at $560^{\circ} \mathrm{C}$.

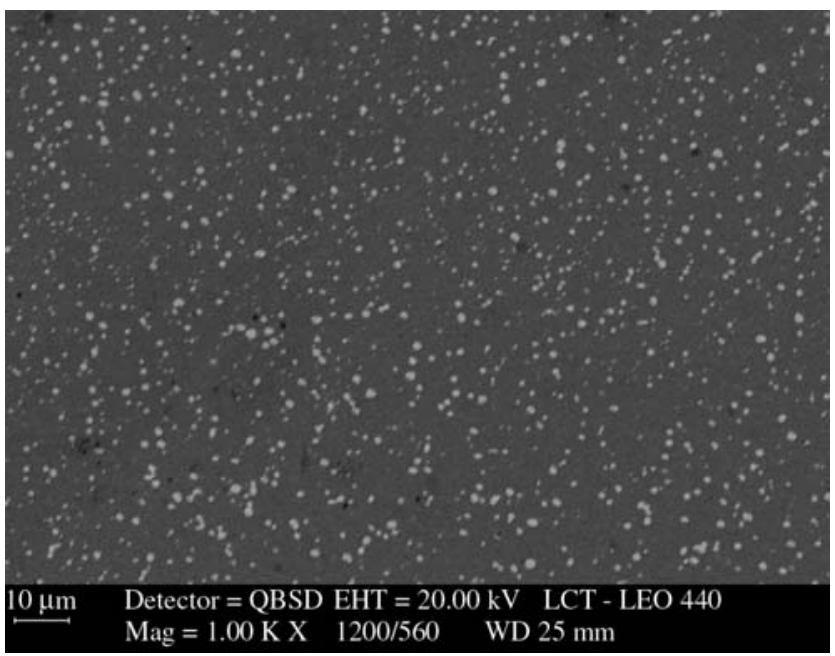

Figure 4. Scanning electron micrograph of Sinter 23 austenitized at $1200^{\circ} \mathrm{C}$ and tempered at $560{ }^{\circ} \mathrm{C}$. 


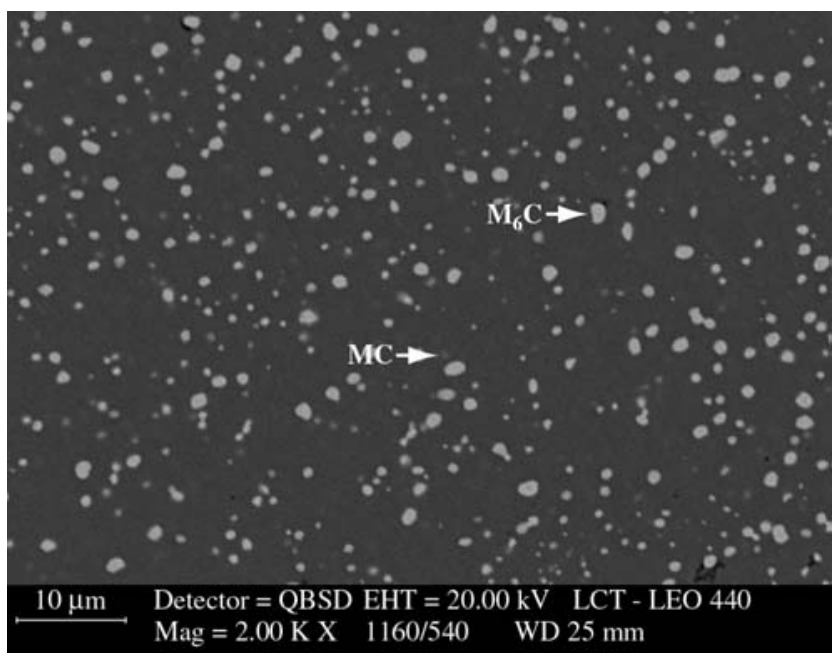

Figure 5. $\mathrm{M}_{6} \mathrm{C}$ and $\mathrm{MC}$ type carbides identified using EDS.

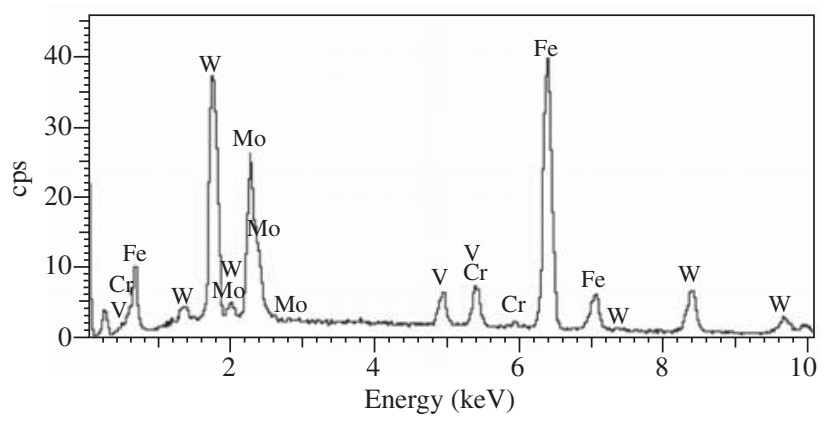

Figure 6. EDS microanalysis of M6C type carbide.

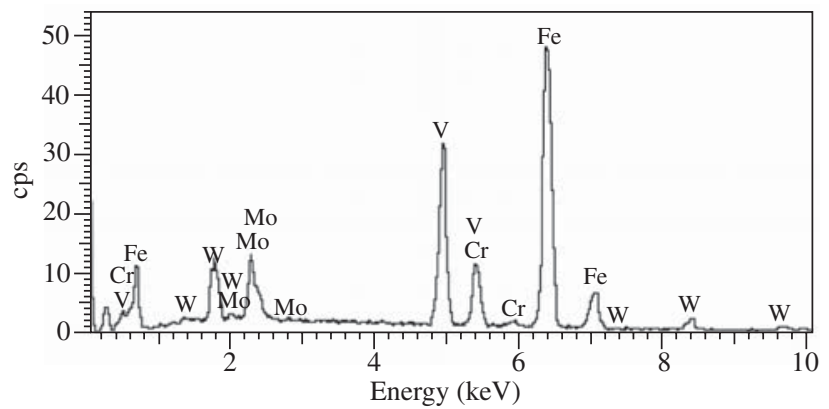

Figure 7. EDS microanalysis of MC type carbide.

resistant to dissolution even at very high temperatures ${ }^{12,13}$.

In the different hardening heat treatments, the hardness after tempering increased with increase in austenitizing temperature. Highest hardness was observed upon tempering at $560^{\circ} \mathrm{C}$, which corresponds to the secondary hardening peak. Attainment of hardness levels as high as this, in the range 960-976 HV, may be a consequence of an increase in the quantity of fine and hard carbide precipitates of the type MC (VC). Figure 8 shows the effect of austenitizing temperature on hardness. The tempering temperature was the same in all cases at $560{ }^{\circ} \mathrm{C}$.

The hardness results for all hardening conditions are listed in Table 2 .

Transverse rupture strength of Sinter 23 decreases in general with increase in austenitizing temperatures for each of the tempering temperatures. This was observed for tempering temperatures of 540 and $560{ }^{\circ} \mathrm{C}$ (secondary hardness peak) as shown in Figures 9 and 10 .

The TRS results for tempering temperatures of 540 and $560{ }^{\circ} \mathrm{C}$

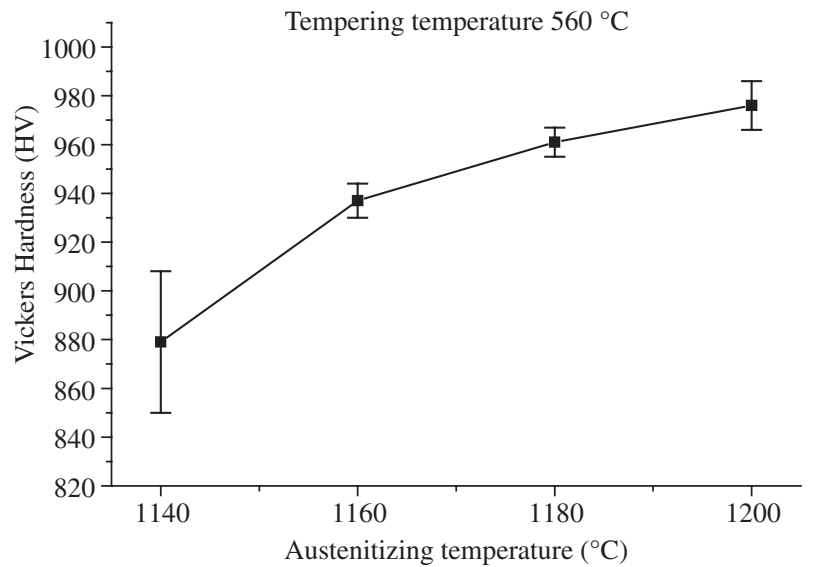

Figure 8. Hardness as a function of austenitizing temperature.

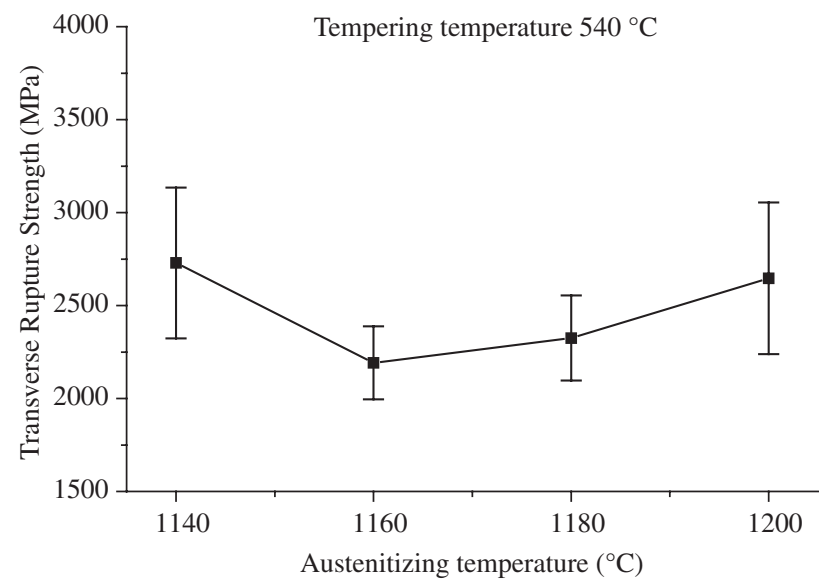

Figure 9. TRS as a function of austenitizing temperature (tempered at $\left.540{ }^{\circ} \mathrm{C}\right)$

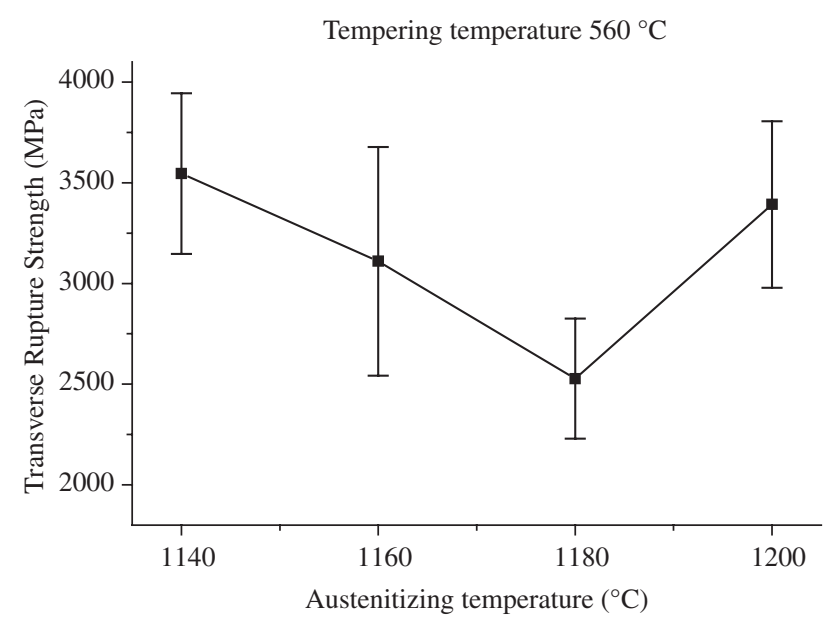

Figure 10. TRS as a function of austenitizing temperature (tempered at $\left.560^{\circ} \mathrm{C}\right)$

indicate that the highest values were observed when the austenitizing temperature was $1140^{\circ} \mathrm{C}$. On the other hand, tempering temperature of $580{ }^{\circ} \mathrm{C}$, well in excess of the secondary hardness peak, resulted in an increase in TRS with increase in austenitizing temperature. The latter was observed for austenitizing temperatures of 1140, 1160 and $1180{ }^{\circ} \mathrm{C}$, as seen in Figure 11. TRS results for tempering temperature of $1200^{\circ} \mathrm{C}$ showed a decrease in TRS (Figure 11). 
Table 2. Vickers hardness results for the twelve hardening conditions.

\begin{tabular}{cllll}
\hline Austenitizing/tempering $\left({ }^{\circ} \mathrm{C}\right)$ & $1140\left({ }^{\circ} \mathrm{C}\right)$ & $1160\left({ }^{\circ} \mathrm{C}\right)$ & $1180\left({ }^{\circ} \mathrm{C}\right)$ & $1200\left({ }^{\circ} \mathrm{C}\right)$ \\
\hline $540\left({ }^{\circ} \mathrm{C}\right)$ & $926 \pm 7$ & $950 \pm 22$ & $932 \pm 15$ & $939 \pm 5$ \\
$560\left({ }^{\circ} \mathrm{C}\right)$ & $879 \pm 29$ & $937 \pm 7$ & $961 \pm 6$ & $976 \pm 10$ \\
$580\left({ }^{\circ} \mathrm{C}\right)$ & $849 \pm 18$ & $893 \pm 10$ & $939 \pm 5$ & $926 \pm 5$ \\
\hline
\end{tabular}

Tempering temperature $580{ }^{\circ} \mathrm{C}$

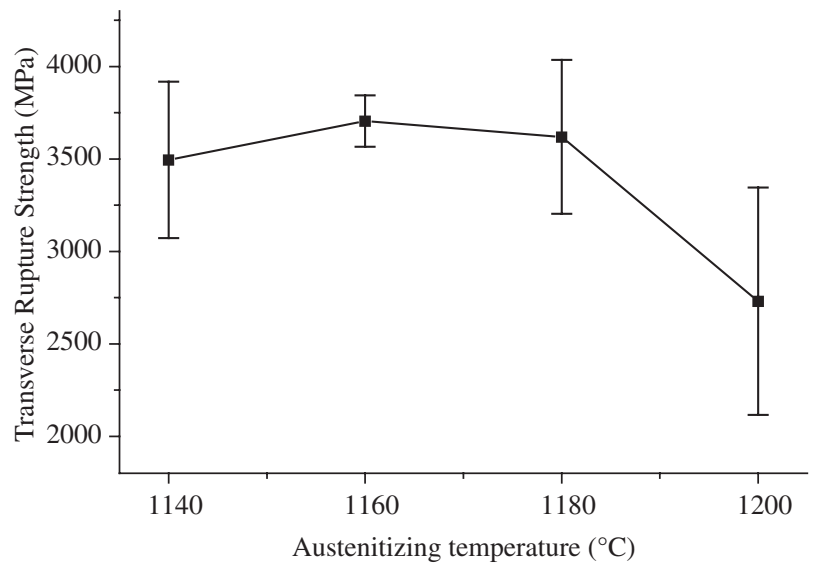

Figure 11. TRS as a function of austenitizing temperature (tempered at $\left.580{ }^{\circ} \mathrm{C}\right)$.

\section{Conclusions}

1. The microstructure of Sinter 23 after a hardening heat treatment consists of a martensitic matrix with carbide precipitates;

2. The carbides present in Sinter 23 after hardening are $\mathrm{M}_{6} \mathrm{C}$ type or a carbide predominantly rich in tungsten and molybdenum and $\mathrm{MC}$ type, or a carbide rich in vanadium;

3. Tempering treatments of $560{ }^{\circ} \mathrm{C}$ which corresponds to the secondary hardening peak resulted in highest hardness and the hardness increased with increase in austenitizing temperatures;

4. Transverse rupture strength of Sinter 23 decreases, in general, with increase in austenitizing temperature. This was observed for tempering temperatures of 540 and $560{ }^{\circ} \mathrm{C}$ (secondary hardness peak). The TRS results for tempering temperatures of 540 and $560{ }^{\circ} \mathrm{C}$ indicate that the highest values were observed for austenitizing temperature of $1140{ }^{\circ} \mathrm{C}(3546 \mathrm{MPa})$; and
5. TRS results for tempering temperature of $580{ }^{\circ} \mathrm{C}$ indicated an increase with austenitizing temperature and attained a peak of almost $4000 \mathrm{MPa}(3705 \mathrm{MPa})$ at $1160{ }^{\circ} \mathrm{C}$ and then decreased at $1200{ }^{\circ} \mathrm{C}$.

\section{Acknowledgments}

The authors wish to thank IPEN, Villares Metals, Hurth Infer, CNPq and FAPESP.

\section{References}

1. Ferraresi D. Fundamentos da usinagem dos metais. Brasil: Editora Edgard Blücher Ltda. 1990; p. 277-328.

2. Bolton J. Heat Treatment of High Speed Steel With Manganese Sulphide And Added Carbides. Metal Powder Report. 1996; 32(1):30-51.

3. Hoyle G. High speed steels. London: ed. Butterworth \& Co. (Publishers). 1988; $222 \mathrm{p}$

4. Metals Handbook - Machining. USA: Joseph R. Davies. 1989; 16: 708732.

5. Stevenson RW. PM tool steels ASM Metals Handbook. USA: Joseph R. Davies. 1984; 7:784.

6. Wilson R. Metallurgy and Heat Treatment of Tool Steels.1975.

7. Ray P, Pal PK, High Speed Steel Semis - Alternate Production Routes. World Conference on Powder Metallurgy. 1990; 2(31):159-169.

8. Froes FM. New technics widening the scope of powder metallurgy. Metal Powder Report. 1994; 49(9):23-26.

9. Thümmler F, Oberacker R. An Introduction to Powder Metallurgy. Series Editors Jenkins I, Wood JV.The Institute of Materials, London, UK. 1993.

10. Greetham G. High Density High Speed Steels. World Conference on Powder Metallurgy. 1990; 2(37):206-216.

11. Takigawa H, Manto H, Kawai N, Homma K. Properties of high-speed steels produced by powder metallurgy. Powder Metallurgy. 1981; 24(4):96-201.

12. Technical Note. Identification of carbides in as-cast 18-4-1 high-speed steels. Journal of the Iron and Steel Institute. 1970; 90-92.

13. Kaiser F, Cohen M. Carbides in high-speed steel - Their nature and quantity. Metal Progress.1952; 79-85. 